\title{
公開シンポジウム
}

\section{6. 慢性期の呼吸理学療法一重症心身障害児への介入}

\author{
○臼田由美子1), 清水 信三2) \\ (1)群㷂県立小児医療センターリハビリテーション科) \\ (2)闬小悠科)
}

近年, 在宅人1呼吸器や在宅酸素機器の進歩 に伴い，呼吸ケアをH常的に行いながらも，在 宅で幕らす重症心身障害枈が増加している。こ れらの症例では，慢性的呼吸障害の状態にある ことが多く，呼吸器感染などを契機に，容易に 急性呼吸不全となる。入院加䝤の急性増悪期の 呼吸ケアと, 外来通院時の慢性期の呼吸ケアは, ともに枈のQOLにとって重装な問題である。

当センターのリハビリテーション科では, 入 院時に呼吸理学㙩法を開始，呼吸ヶア指導を外 来にて継続する䬺例が増加している。

【目的】急性增患期には全道内分泌物貯留や無 気肺の改䈍と子防，呼吸パ夕ーンの調整及び換 気改善が主な月的となる。慢性期の指導では, 予防的ケアと長期臥休により発生する二次的合

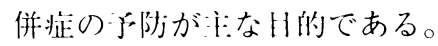

【方法】他動的な朋手手技が注:であるが, 確 実・簡便に行える器機の導入も効果的である。 呼吸理学㙩法の主手順は, 上気道の確保, 体 位排痰に配慮した姿勢变換，用手呼吸介助，咳 介助, 呼吸パターン及び帘静呼吸を考慮したポ ジショニングである。リラクゼーションや胸郭 脊柱の叮動域の確保が深い呼吸を促すのに必要 である症例もある。

【急性期の症例】入院時に呼吸理学療法を行っ た重症心身障害枈の原疾患は脳性麻痺，脳症後 遺症，神経筋疾患であり，平均年齢 6.8 歳であ った。

【慢性期の証例】介護者に対し，日常の生活管 理と呼吸ヶアを指導している。家庭の介護力を 考虑し，介護㶦担の軽減につながる呼吸ケアの
プランを立てる仏用がある。

【呼吸理学療法の効果判定の試み】呼吸管理モ ニターコズモ8100（NOVAMETRIX製）にて, 呼吸理学療法前後の呼吸機能の変化を, 非侵襲 的に確認することを試みた。

【症例 1】脳症後遺症, 気管切開の 4 歳児。肺 炎及び無気肺のため入院加療となり呼吸理学療 法を開始した。換気量とフローの増加, 呼吸パ ターンの変化が認められ，3 日目にレントゲン 上の改善が認められた。

【症例 2】福山型筋ジストロフィー症の10歳児。 肺炎及び無気肺のため入院加療。1 日 2 回の力 フマシーンを利用した呼吸理学療法の直後に多 量の分泌物が喀痰され, 呼吸カーブの改善と一 回換気量と分時換気量の増加が認められた。

【症例 3 】脳症後遺症の 8 歳児。肺炎・無気肺 による入院時に呼吸理学療法を開始し, 現在は 外来にて, 運動療法, 呼吸ケア, 嚥下訓練, ポ ジショニングの指導を継続している。吸入物は 多量であり，呼吸パターンの改善が認められた。 【症例 4 】気管切開, 在宅人工呼吸器の白質ジ ストロフィー症の 7 歳児。外来にて全身的な運 動療法と在宅での運動と呼吸ケアを指導してい る。

【今後の課題】手技の選択や介入のプロトコル， 適応となる病態の検討が必要と考えられる。ま た, 病棟との連携や地域訪問看護との連携, 理 学療法士の経験不足や呼吸器疾患への知識不足 も課題である。医師及びコメディカルによるケ 一ス検討の場を多く持つことにより解決可能な 課題も多いと考えている。 